\title{
Examination of operation specimens from patients with spinal tuberculosis for tubercle bacilli
}

\author{
BW ALLEN, DA MITCHISON, JANET DARBYSHIRE, WWK CHEW, M GABRIEL \\ From the Medical Research Council Unit for Laboratory Studies of Tuberculosis Royal Postgraduate Medical \\ School, London W12 OHS, The Medical Research Council Tuberculosis and Chest Diseases Unit, Brompton \\ Hospital, London SW3 6HP, and Ruttonjee Sanatorium, Hong Kong.
}

SUMMARY Operation specimens from 52 Hong Kong patients considered to have tuberculosis of the spine were sent at $-78^{\circ} \mathrm{C}$ to London where they were cultured on two Löwenstein-Jensen medium slopes, a slope of 7H11 medium made selective with antibiotics and in two bottles of selective liquid Kirchner medium. Cultures of $M$ tuberculosis, usually with only scanty colonies, were obtained from 37 of the patients. Pus and caseous matter yielded more positive cultures and more numerous colonies than other specimens, but eight of the 37 patients yielded positive cultures only from tissues lining abscess walls or from bone or intervertebral disc specimens. Cultures in Kirchner medium were never contaminated and twice as many were positive as cultures on the slopes; nine patients had cultures positive only on Kirchner medium. It is recommended that (i) a variety of operation specimens, always including pus or caseous material in volumes of at least $1 \mathrm{ml}$, should be sent for bacteriology; (ii) specimens should be cultured in selective Kirchner medium, with or without Löwenstein-Jensen slopes; (iii) cultures should be incubated for a minimum of 8-9 wk.

Examination of specimens other than sputum for tubercle bacilli is a substantial part of the work of many British bacteriology laboratories. At Hammersmith Hospital, $33 \%$ of all isolates of Mycobacterium tuberculosis over a three-year period were obtained from such specimens. ${ }^{1}$ The number of viable bacilli that they contain is often very small, especially those from closed lesions containing large volumes of caseous pus. An opportunity to investigate the efficiency of current bacteriological techniques for this type of specimen was afforded by a Medical Research Council collaborative study of chemotherapy regimens in the treatment of spinal tuberculosis in Hong Kong. All patients had the operation of radical anterior resection and bone grafting, as described in a previous study. ${ }^{2}$ Specimens obtained at operation were examined in Hong Kong and were also flown to London to be examined. We report here on aspects of the bacteriology of these specimens, particularly the value of culture in selective liquid Kirchner medium ${ }^{3}$ as well as on conventional Löwenstein-Jensen medium slopes.

Accepted for publication 12 January 1983

\section{Methods}

\section{PATIENTS STUDIED}

The main results of the current study will be published when all patients have completed three years from the start of chemotherapy. Radical anterior resection and bone grafting was done on all patients and a comparison was made between six- and nine-month durations of chemotherapy with daily isoniazid and rifampicin plus twice-weekly streptomycin. The operation was usually undertaken within 14 days of the start of chemotherapy. Specimens taken at operation were examined fresh at the laboratory of the Ruttonjee Sanatorium in Hong Kong and were also sent at $-78^{\circ} \mathrm{C}$ in solid $\mathrm{CO}_{2}$ by air to London. Further specimens were examined histologically by Professor J Ball, University of Manchester.

\section{CULTURE MEDIA}

The media used were slopes of Löwenstein-Jensen medium (LJ), Löwenstein-Jensen medium containing $0.5 \%$ sodium pyruvate $(\mathrm{LJ}+\mathrm{P})$, Middlebrook's $7 \mathrm{H} 11$ oleic acid-albumin agar medium ${ }^{4}$ (Difco) (7H11) and liquid Kirchner medium.s Kirchner medium was prepared without penicillin and was 
modified by the addition of casein hydrolysate $(0.5$ $\mathrm{g} / \mathrm{l})$ and $10 \%$ calf serum in place of horse serum. Kirchner medium and 7H11 slopes were made selective by the addition of polymyxin $B(200 \mathrm{U} / \mathrm{ml})$, carbenicillin $(100 \mathrm{mg} / \mathrm{l})$, trimethoprim $(10 \mathrm{mg} / \mathrm{l})$, and amphotericin B $(10 \mathrm{mg} / \mathrm{l}){ }^{6}$ Media were dispensed in screw-capped Universal containers, the Kirchner medium in $10 \mathrm{ml}$ and the slopes in $5 \mathrm{ml}$ volumes.

\section{TREATMENT OF SPECIMENS \\ London}

When more than $5 \mathrm{ml}$ of pus was received, the specimen was divided into two aliquots, each treated as a separate specimen. Soft tissues were chopped with scissors and ground with sterile water in polytetrafluorethylene/glass grinders or in Griffith's tubes. Specimens of bone, disc or cartilage were chopped into small pieces, mixed with $2 \mathrm{ml}$ sterile water and shaken mechanically for $5 \mathrm{~min}$ to yield a fluid extract. The specimens or their extracts were examined by fluorescence microscopy of auraminestained smears ${ }^{7}$ and by cultures. Blood agar plates were inoculated and incubated overnight to detect organisms other than mycobacteria. For the isolation of mycobacteria, an $\mathrm{LJ}$, an $\mathrm{LJ}+\mathrm{P}$ and a $7 \mathrm{H} 11$ slope were each inoculated with two loopfuls (0.02 $\mathrm{ml}$ ); one bottle of selective Kirchner medium was inoculated with a small $(0.2 \mathrm{ml})$ volume (KS) and the second with a large $(0.8 \mathrm{ml})$ volume $(\mathrm{KL})$ of the specimen or its extract. Cultures were incubated at $37^{\circ} \mathrm{C}$ without added $\mathrm{CO}_{2}$. The $\mathrm{LJ}, \mathrm{LJ}+\mathrm{P}$ and $7 \mathrm{H} 11$ slopes were examined for growth at weekly intervals for 8-9 wk. The KS and KL bottles were examined weekly and subcultivated onto $\mathrm{LJ}$ slopes as soon as growth first appeared or after five weeks' incubation; the LJ slopes were then incubated for a further three weeks. All cultures of mycobacteria were identified by standard procedures and, when available, cultures from two specimens from each patient were tested for their sensitivity to isoniazid, rifampicin and streptomycin. ${ }^{8}$

\section{Hong Kong}

Each specimen was inoculated onto four LJ slopes, two following decontamination with $\mathrm{NaOH}$ and two without decontamination.

\section{Results}

A total of 60 patients was admitted to the study with a clinical diagnosis of spinal tuberculosis. This report is concerned with the 52 patients for whom the diagnosis was confirmed by bacteriological or histological examination of their operation specimens and does not include two patients in the main analysis of the study whose diagnosis was based on clinical and radiological findings with equivocal histology and negative bacteriology. M tuberculosis was isolated from operation specimens in $46(88 \%)$ of the 52 patients, and the remaining six had histological evidence of tuberculosis but no mycobacteria were isolated. Bacteriology was done on all 52 patients in London but only 47 patients also had bacteriology in Hong Kong. From these 47 patients, positive cultures were obtained from $33(70 \%)$ in Hong Kong and from $32(68 \%)$ in London. Positive cultures were obtained from specimens from 37 of the 52 patients examined in London. These 52 patients yielded 321 specimens, an average of $6 \cdot 2$ specimens per patient (range 3-10). The specimens took an average of 5.4 days in transit between the operation in Hong Kong and laboratory processing in London.

There was no association between the duration of chemotherapy prior to operation and the isolation of $M$ tuberculosis. The proportions of patients with positive cultures were $70 \%$ of 27 patients with periods of $1-7$ days, $71 \%$ of 17 patients with periods of 8-14 days and $75 \%$ of 8 patients with periods of 15-41 days.

The organisms from 33 of the 37 patients with positive cultures were sensitive to isoniazid, streptomycin and rifampicin; one patient had strains resistant to isoniazid alone, another had strains resistant to streptomycin alone and two had strains resistant to isoniazid and streptomycin. In each of the four patients with resistant cultures, the second culture from a different specimen had the same sensitivity pattern.

\section{NATURE OF THE SPECIMEN}

The results of direct smear and culture examination in London according to the type of specimen are set out in Table 1. A positive smear was found in 64 $(20 \%)$ of the 321 specimens, the standardised gradings ${ }^{7}$ being scanty $(+)$ in $87 \%$ of the 64 specimens and moderate $(++)$ in $13 \%$; no smears were graded heavy $(+++)$. A positive culture was obtained from $142(44 \%)$ of the 321 specimens. Growth was scanty; of the 62 specimens that were positive on the single LJ slope, all but two yielded less than $20 \mathrm{col}-$ onies and 22 yielded 1 colony, 16 yielded $2-3$ colonies, 7 yielded 4-5 colonies, and 9 yielded $6-10$ colonies (Table 2).

Positive smears and cultures were obtained slightly more often from specimens of pus than from other types of specimen (Table 1). The grading on the single LJ slope showed that the pus specimens were not only more often positive but also yielded more colonies (Table 2 ). Thus, growth of $\geqslant 6$ colonies was obtained in $12(41 \%)$ of 29 positive pus 
Table 1 Direct smear and culture results according to type of operation specimen

\begin{tabular}{|c|c|c|c|c|c|c|c|c|}
\hline \multirow[t]{3}{*}{ Specimen } & \multirow{3}{*}{$\begin{array}{l}\text { Total } \\
\text { specimens } \\
(A)\end{array}$} & \multicolumn{5}{|c|}{ Smear result } & \multirow{2}{*}{\multicolumn{2}{|c|}{$\frac{\text { Culture result }}{\text { Total positive }}$}} \\
\hline & & \multirow[t]{2}{*}{$N A$} & \multirow[t]{2}{*}{+} & \multirow[t]{2}{*}{++} & \multicolumn{2}{|c|}{ Total positive } & & \\
\hline & & & & & No & $\%$ of $A$ & No & $\%$ of $A$ \\
\hline $\begin{array}{l}\text { Pus } \\
\text { Caseum }\end{array}$ & $\begin{array}{l}79 \\
22\end{array}$ & $\begin{array}{l}0 \\
0\end{array}$ & $\begin{array}{r}24 \\
6\end{array}$ & $\begin{array}{l}4 \\
0\end{array}$ & $\begin{array}{r}28 \\
6\end{array}$ & $\begin{array}{l}40 \\
27\end{array}$ & $\begin{array}{l}41 \\
10\end{array}$ & $\begin{array}{l}52 \\
45\end{array}$ \\
\hline $\begin{array}{l}\text { Granulation tissue } \\
\text { Soft tissue sloughs } \\
\text { Abscess wall }\end{array}$ & $\begin{array}{r}48 \\
34 \\
8\end{array}$ & $\begin{array}{l}0 \\
0 \\
0\end{array}$ & $\begin{array}{l}6 \\
8 \\
0\end{array}$ & $\begin{array}{l}0 \\
2 \\
0\end{array}$ & $\begin{array}{r}6 \\
10 \\
0\end{array}$ & $\begin{array}{r}12 \\
29 \\
0\end{array}$ & $\begin{array}{r}19 \\
15 \\
2\end{array}$ & $\begin{array}{l}40 \\
44 \\
25\end{array}$ \\
\hline $\begin{array}{l}\text { Avascular bone } \\
\text { Sequestrum } \\
\text { Disc } \\
\text { Cartilage plate } \\
\text { End plate }\end{array}$ & $\begin{array}{r}51 \\
35 \\
41 \\
2 \\
1\end{array}$ & $\begin{array}{l}0 \\
2 \\
2 \\
0 \\
0\end{array}$ & $\begin{array}{l}5 \\
4 \\
2 \\
0 \\
1\end{array}$ & $\begin{array}{l}0 \\
0 \\
2 \\
0 \\
0\end{array}$ & $\begin{array}{l}5 \\
4 \\
4 \\
0 \\
1\end{array}$ & $\begin{array}{r}10 \\
11 \\
10 \\
0 \\
100\end{array}$ & $\begin{array}{r}23 \\
12 \\
19 \\
0 \\
1\end{array}$ & $\begin{array}{r}45 \\
34 \\
46 \\
0 \\
100\end{array}$ \\
\hline Total & 321 & 4 & 56 & 8 & 64 & 20 & 142 & 44 \\
\hline
\end{tabular}

$\mathrm{NA}=$ not available

Table 2 Culture results of various types of operation specimen on the single Löwenstein-Jensen medium slope

\begin{tabular}{|c|c|c|c|c|c|c|c|}
\hline \multirow[t]{3}{*}{ Specimen } & \multirow{3}{*}{$\begin{array}{l}\text { Total specimens } \\
(A)\end{array}$} & \multicolumn{6}{|c|}{ Culture result } \\
\hline & & \multirow[t]{2}{*}{$C T$} & \multirow{2}{*}{$\begin{array}{l}1-5 \\
\text { cols }\end{array}$} & \multirow{2}{*}{$\begin{array}{l}6-19 \\
\text { cols }\end{array}$} & \multirow{2}{*}{$\begin{array}{l}20-100 \\
\text { cols }\end{array}$} & \multicolumn{2}{|c|}{ Total positive } \\
\hline & & & & & & No & $\%$ of $A$ \\
\hline $\begin{array}{l}\text { Pus } \\
\text { Caseum }\end{array}$ & $\begin{array}{l}79 \\
22\end{array}$ & $\begin{array}{l}2 \\
0\end{array}$ & $\begin{array}{r}17 \\
1\end{array}$ & $\begin{array}{r}10 \\
2\end{array}$ & $\begin{array}{l}2 \\
0\end{array}$ & $\begin{array}{r}29 \\
3\end{array}$ & $\begin{array}{l}37 \\
14\end{array}$ \\
\hline $\begin{array}{l}\text { Granulation tissue } \\
\text { Soft tissue sloughs } \\
\text { Abscess wall }\end{array}$ & $\begin{array}{r}48 \\
34 \\
8\end{array}$ & $\begin{array}{l}0 \\
1 \\
0\end{array}$ & $\begin{array}{l}9 \\
2 \\
0\end{array}$ & $\begin{array}{l}0 \\
1 \\
0\end{array}$ & $\begin{array}{l}0 \\
0 \\
0\end{array}$ & $\begin{array}{l}9 \\
3 \\
0\end{array}$ & $\begin{array}{r}19 \\
9 \\
0\end{array}$ \\
\hline $\begin{array}{l}\text { Avascular bone } \\
\text { Sequestrum } \\
\text { Disc } \\
\text { Cartilage plate } \\
\text { End plate }\end{array}$ & $\begin{array}{r}51 \\
35 \\
41 \\
2 \\
1\end{array}$ & $\begin{array}{l}1 \\
0 \\
0 \\
0 \\
0\end{array}$ & $\begin{array}{l}7 \\
4 \\
5 \\
0 \\
0\end{array}$ & $\begin{array}{l}0 \\
1 \\
1 \\
0 \\
0\end{array}$ & $\begin{array}{l}0 \\
0 \\
0 \\
0 \\
0\end{array}$ & $\begin{array}{l}7 \\
5 \\
6 \\
0 \\
0\end{array}$ & $\begin{array}{r}14 \\
14 \\
15 \\
0 \\
0\end{array}$ \\
\hline Total & 321 & 4 & 45 & 15 & 2 & 62 & 19 \\
\hline
\end{tabular}

$\mathrm{CT}=$ contaminated.

Table 3 Culture positivity and contamination rate with different combinations of media

\begin{tabular}{llllll}
\hline Media used & \multicolumn{2}{c}{ Positive culture on any medium } & & \multicolumn{2}{c}{ Contaminated on all media } \\
\cline { 2 - 3 } \cline { 5 - 6 } & No & \% of 142 positive specimens & & No & \% of 321 specimens examined \\
\hline LJ & 62 & $43 \cdot 7$ & 4 & $1 \cdot 2$ \\
LJ + P & 56 & $39 \cdot 4$ & 4 & $1 \cdot 2$ \\
LJ, LJ + P & 75 & $52 \cdot 8$ & 3 & $0 \cdot 9$ \\
7H 11 & 49 & $34 \cdot 5$ & 1 & $0 \cdot 3$ \\
KS & 121 & $85 \cdot 2$ & 0 & 0 \\
KL & 124 & $87 \cdot 3$ & 0 & 0 \\
KS, KL & 139 & $97 \cdot 9$ & 0 & 0 \\
LJ, LJ + P, KL & 129 & $90 \cdot 8$ & 0 & 0 \\
LJ, LJ + P, KS, KL & 141 & $99 \cdot 3$ &
\end{tabular}

LJ = Löwenstein-Jensen slope; $L J+P=$ Löwenstein-Jensen + pyruvate; 7H11 = Selective 7H11 slope; KS = selective Kirchner liquid medium: small inoculum; $\mathrm{KL}=$ selective Kirchner liquid medium: large inoculum.

specimens but in only $5(15 \%)$ of 33 positive cultures from other specimens $(p<0.05)$. The examination of other types of specimens in addition to pus or caseum was however of diagnostic value. Of the 37 patients from whose specimens $M$ tuberculosis was isolated, $29 .(78 \%)$ had a positive culture from pus or caseum, but six of the remaining eight patients had positive cultures from granulation tis- sue, soft tissue sloughs or abscess wall and the last two patients had positive cultures from bone specimens and in one from a disc also.

RELATIVE VALUE OF MEDIA

In London, $M$ tuberculosis was isolated from all five media inoculated in only $34(23.9 \%)$ of the 142 specimens with a positive culture in any medium. 
Table 4 Speed with which cultures became positive

\begin{tabular}{|c|c|c|c|c|c|}
\hline \multirow{2}{*}{$\begin{array}{l}\text { Incubation } \\
\text { period (wk) }\end{array}$} & \multicolumn{5}{|c|}{ Cumulative percentage positive on: } \\
\hline & $L J$ & $L J+P$ & $7 H 11$ & $K S^{*}$ & $K L^{*}$ \\
\hline $\begin{array}{l}3- \\
4- \\
5- \\
6- \\
7- \\
8-9\end{array}$ & $\begin{array}{c}16.1 \\
22.6 \\
61 \cdot 3 \\
80.6 \\
95 \cdot 2 \\
100\end{array}$ & $\begin{array}{c}17 \cdot 9 \\
26 \cdot 8 \\
62 \cdot 5 \\
82 \cdot 1 \\
96 \cdot 4 \\
100\end{array}$ & $\begin{array}{r}18.4 \\
18.4 \\
51.0 \\
81.6 \\
95.9 \\
100\end{array}$ & $\begin{array}{r}9 \cdot 1 \\
27 \cdot 3 \\
56 \cdot 2 \\
- \\
-\end{array}$ & $\begin{array}{r}9.7 \\
27.4 \\
56 \cdot 5 \\
- \\
-100\end{array}$ \\
\hline
\end{tabular}

${ }^{*}$ Presence of growth in the liquid KS and KL media was read until 5 weeks at which time a subculture was made that was finally read at $8 \mathrm{wk}$. Although readings of the subcultures were made, the week at which the slope first became positive was not recorded.

The Kirchner liquid medium bottles (KS and KL) were much more efficient than the slopes (Table 3 ). Thus a positive culture was obtained from $43.7 \%$ of LJ slopes but from $87.3 \%$ of the KL bottles inoculated with the 142 positive specimens. There was little difference between the KS and KL bottles, but inoculation of both bottles increased the proportion of positive results to $97.9 \%$. Inclusion of the $\mathrm{LJ}$ and $\mathrm{LJ}+\mathrm{P}$ slopes with them only increased the yield to 99.3\%. The 7H11 slope appeared slightly less efficient than the LJ slopes. Of the 37 patients with positive bacteriology, $27(73 \%)$ had a positive culture on the $\mathbf{L J}$ or $\mathrm{LJ}+\mathrm{P}$ slopes and also in Kirchner medium, nine had a positive culture only in Kirchner medium (KS or $\mathrm{KL}$ ) and one had a positive culture only on the 7H11 slope. None was positive only on the $\mathrm{LJ}$ or $\mathrm{LJ}+\mathrm{P}$ slopes.

Only five of the specimens yielded growth on blood agar medium overnight and of these two also contaminated one or more of the five media for mycobacteria. The contamination rate in the five media was low (1.2\%) for the $\mathrm{LJ}$ and $\mathrm{LJ}+\mathrm{P}$ slopes, but none of the KS and KL bottles was contaminated (Table 3 ). The perid of incubation necessary to obtain growth of $M$ tuberculosis was rather long, only about one-quarter of positive results being obtained at $4 \mathrm{wk}$ and about one-fifth in the final 2 wk after the six-week reading (Table 4). It should be noted that although positive results were obtained at about the same time in Kirchner medium as on the slopes, an additional two weeks was usually required for a subculture from Kirchner medium on to a slope to grow and be available for identification and sensitivity tests.

\section{Discussion}

The bacteriology of the operation specimens from spinal tuberculosis is of particular interest because the great majority contained very few viable tubercle bacilli, a finding characteristic of bone and joint tuberculosis. ${ }^{910}$ For instance, only one to five col- onies were obtained on the $\mathrm{LJ}$ slopes of $73 \%$ of the 62 specimens that yielded growth. Specimens of pus and caseous matter were most likely to be positive, but $24 \%$ of the patients had no growth from such specimens and yet yielded a culture from the tissues lining an abscess or even from bone. One important conclusion is that a variety of operation specimens should be submitted for bacteriology.

Because of the paucity of viable bacilli in the specimens, the sensitivity of the culture method used was subjected to a particularly stringent test. The most important finding was that Kirchner liquid medium bottles yielded cultures of $M$ tuberculosis about twice as often as the $\mathbf{L J}$ or $\mathbf{L J}+\mathrm{P}$ slopes. Furthermore, nine of 37 patients with positive cultures had these only on Kirchner medium, whereas there were none with cultures positive only on the slopes. Liquid LJ medium has also been found superior to solid LJ slopes in culture from bone and joint tuberculosis. ${ }^{11}$ The superiority of Kirchner medium almost certainly lay in the greater volume of the inoculum of pus or tissue added to the liquid medium than to the solid slopes. While addition of a larger inoculum might also be expected to lead to a higher contamination rate, the presence of antibiotics in the Kirchner medium eliminated contamination totally. In view of the substantially higher isolation rate and the absence of contamination, the value of inoculating any medium in addition to the Kirchner bottles is questionable. However, the use of conventional $\mathrm{LJ}$ and $\mathrm{LJ}+\mathrm{P}$ slopes still retains a few small advantages. Although positive cultures were obtained after much the same incubation periods in liquid and on solid media, subcultivation of the growth in liquid medium on to $\mathrm{LJ}$ slopes increased by about two weeks the interval until a culture was available for identification and sensitivity tests. A more theoretical disadvantage of the Kirchner medium is that the selective antibiotics included might inhibit some species of mycobacteria other than tubercle bacilli. ${ }^{6}$ These organisms very rarely cause spinal tuberculosis. Indeed only three instances were quoted in a very thorough review of the literature. ${ }^{12}$ It is fair to conclude that specimens from spinal tuberculosis, and probably from other closed sites as well, should always be inoculated into at least two bottles of selective Kirchner medium. They should also be seeded onto an $\mathrm{LJ}$ and an $\mathrm{LJ}+$ $P$ or at least on to a single $\mathbf{L J}+\mathbf{P}$ slope; inclusion of the pyruvate slope is to encourage growth of $M$ bovis, though any advantages gained will be small. The inclusion of the 7H11 slope did not appear to have been of value and there seems to be no justification for including it in the set that is routinely inoculated. A further conclusion is that specimens should have volumes, when available, of 
at least $1 \mathrm{ml}$, the total volume inoculated into the two Kirchner medium bottles, and should not be taken only as swabs.

In view of the value of Kirchner medium, it is surprising that, of the 47 patients whose specimens were examined in both laboratories, positive cultures were found in $70 \%$ in the Hong Kong laboratory, which used LJ slopes only, and $68 \%$ in the London laboratory, which inoculated Kirchner medium in addition. The failure to obtain a higher proportion in London may have been due to transport of the specimens at $-78^{\circ} \mathrm{C}$ from Hong Kong, since freezing of bacilli always results in some loss of viability. Transport at $4^{\circ} \mathrm{C}$ might have preserved greater viability, but would have been difficult to arrange.

An additional aspect of laboratory technique to be noted is that about one-fifth of the cultures on slopes became positive only between the reading at $6 \mathrm{wk}$ and at $8 \mathrm{wk}$. Correspondingly, the $\mathrm{LJ}$ subculture from Kirchner medium read between 6 and 8 wk yielded almost half of the positive cultures. Thus, it is essential that cultures should be incubated for a nominal $8 \mathrm{wk}$, which implies that some will be incubated for nearly $9 \mathrm{wk}$, instead of the more usual six-week period. It would also be worth seeing whether prolonging the incubation period beyond 8 wk would increase the yield. These long incubation periods seem to be due to the small number of colonies isolated and are not peculiar to specimens from spinal tuberculosis. A series of cultures from sputum specimens with matched low colony counts took just as long to yield growth (data not tabulated here).

Inoculation of pus and other operation specimens into guinea-pig offers the same advantage as the use of selective culture medium in that the method detects a small number of viable tubercle bacilli present in moderately large volumes of material. Despite its potential advantage, guinea-pig inoculation was not used in the study nor is it recommended in the routine bacteriological diagnosis of tuberculosis from any type of specimen for the following reasons: (i) the results of guinea-pig inoculation have been found to be no better than those obtained by culture $;^{1314}$ (ii) guinea-pigs are far more expensive than culture medium; (iii) the inoculation, housing and examination of tuberculosis guinea-pigs require safety precautions in the animal house that are becoming much more stringent and thus increase man-power requirements and the cost of the method, and (iv) in the current climate of opinion the use of experimental animals should be avoided whenever possible.

The specimens obtained for this investigation were from patients admitted to a study conducted by the MRC Working Party on Spinal Tuberculosis.

\section{References}

1 Allen BW, Darrell JH. Extrapulmonary tuberculosis. A potential source of laboratory acquired infection. J Clin Pathol? 1981;34:404-7.

${ }^{2}$ Medical Research Council. A controlled trial of anterior spinal fusion and debridement in the surgical management of tuber- $\delta$ culosis of the spine in patients on standard chemotherapy: a study in Hong Kong. Br J Surg 1974;61:853-66.

${ }^{3}$ Mitchison DA, Aber VR. Culture of specimens other than sputum for mycobacteria. J Clin Pathol 1974;27:883-7.

${ }^{4}$ Cohn ML, Waggoner RF, McClatchy JK. The $7 \mathrm{H} 11$ medium for the cultivation of mycobacteria. Am Rev Respir Dis 1968;98:295-6.

s Public Health Laboratory Service. Cultivation of Mycobacterium $\overrightarrow{0}$ tuberculosis. Part VI The choice of culture media for the isola- $\infty$ tion of tubercle bacilli from sputum. Mon Bul Min Health 1958;17:112-8.

- Mitchison DA, Allen BW, Carrol L, Dickinson JM, Aber VR. A selective oleic acid albumin agar medium for tubercle bacilli. $J$ Med Microbiol 1972;5:165-75.

7 Mitchison DA. Standard smears for grading the content of acidfast bacilli in sputum. Tubercle 1966;47:289-91.

${ }^{8}$ Medical Research Council. Cooperative controlled trial of a $\vec{F}$ standard regimen of streptomycin, PAS and isonazid and three alternative regimens of chemotherapy in Britain. Tubercle 1973;54:99-129.

9 Canetti G, Debeyre J, de Seze S. Sterilisation des lesions de la tuberculose osteo-articulaire par la chimiotherapie antibacillaire. Rev Tuberc, Paris 1957;21:1337-44.

${ }^{10}$ Debeaumont A. Bacteriologie de la tuberculose osteo-articulaire 0 sous chimiotherapie. Prog Explor Tuberc 1966;15:125-88.

"Mathur M, Bhatia VN, Agarwal DS, Abbott MG. Detection of acid fast bacilli in material from cases of bone and joint tuberculosis. Ind J Pathol Microbiol 1980;23:255-60.

${ }^{12}$ Wolinsky E. Non tuberculous mycobacteria and associated dis- $\mathrm{O}$ eases. State of the art. Am Rev Respir Dis 1979;119:107-59.

${ }^{13}$ Marks J. Ending the routine guinea-pig test. Tubercle 1972;53:31-4.

${ }^{14}$ Mitchison DA, Allen BW, Lambert RA. Selective media in the $N$ isolation of tubercle bacilli from tissues.J Clin Pathol 1973;26:250-2.

Requests for reprints to: Dr DA Mitchison, Royal Postgraduate Medical School, Hammersmith Hospital, Duco Cane Road, London W12 0HS, England. 